\title{
Space- and Ground-Based Geophysical Data Tracking of Magma Migration in Shallow Feeding System of Mount Etna Volcano
}

\author{
Marco Laiolo ${ }^{1, * \mathbb{C}}$, Maurizio Ripepe ${ }^{2}$, Corrado Cigolini ${ }^{1}$, Diego Coppola ${ }^{1}$, \\ Massimo Della Schiava ${ }^{2}$, Riccardo Genco ${ }^{2}$, Lorenzo Innocenti ${ }^{2}$, Giorgio Lacanna ${ }^{2}$, \\ Emanuele Marchetti ${ }^{2}$, Francesco Massimetti ${ }^{1,2}$ and Maria Cristina Silengo ${ }^{2}$ \\ 1 Dipartimento di Scienze della Terra, Università di Torino, V. Valperga Caluso 4; 10125 Torino, Italy; \\ corrado.cigolini@unito.it (C.C.); diego.coppola@unito.it (D.C.); francesco.massimetti@unito.it (F.M.) \\ 2 Dipartimento di Scienze della Terra, Università di Firenze, V. G. La Pira 4; 50121 Firenze, Italy; \\ maurizio.ripepe@unifi.it (M.R.); massimo.dellaschiava@unifi.it (M.D.S.); riccardo.genco@unifi.it (R.G.); \\ lorenzo.innocenti@unifi.it (L.I.); giorgio.lacanna@unifi.it (G.L.); emanuele.marchetti@unifi.it (E.M.); \\ mariacristina.silengo@unito.it (M.C.S.) \\ * Correspondence: marco.laiolo@unito.it
}

Received: 29 April 2019; Accepted: 16 May 2019; Published: 18 May 2019

\begin{abstract}
After a month-long increase in activity at the summit craters, on 24 December 2018, the Etna volcano experienced a short-lived lateral effusive event followed by a rapid resumption of low-level explosive and degassing activity at the summit vents. By combining space (Moderate Resolution Imaging Spectroradiometer; MODIS and SENTINEL-2 images) and ground-based geophysical data, we track, in near real-time, the thermal, seismic and infrasonic changes associated with Etna's activity during the September-December 2018 period. Satellite thermal data reveal that the fissural eruption was preceded by a persistent increase of summit activity, as reflected by overflow episodes in New SouthEast Crater (NSE) sector. This behavior is supported by infrasonic data, which recorded a constant increase both in the occurrence and in the energy of the strombolian activity at the same crater sectors mapped by satellite. The explosive activity trend is poorly constrained by the seismic tremor, which shows instead a sudden increase only since the 08:24 GMT on the 24 December 2018, almost concurrently with the end of the infrasonic detections occurred at 06:00 GMT. The arrays detected the resumption of infrasonic activity at 11:13 GMT of 24 December, when tremors almost reached the maximum amplitude. Infrasound indicates that the explosive activity was shifting from the summit crater along the flank of the Etna volcano, reflecting, with the seismic tremor, the intrusion of a gas-rich magma batch along a $\sim 2.0 \mathrm{~km}$ long dyke, which reached the surface generating an intense explosive phase. The dyke propagation lasted for almost $3 \mathrm{~h}$, during which magma migrated from the central conduit system to the lateral vent, at a mean speed of $0.15-0.20 \mathrm{~m} \mathrm{~s}^{-1}$. Based on MODIS and SENTINEL 2 images, we estimated that the summit outflows erupted a volume of lava of $1.4 \mathrm{Mm}^{3}\left( \pm 0.5 \mathrm{Mm}^{3}\right)$, and that the lateral effusive episode erupted a minimum volume of $0.85 \mathrm{Mm}^{3}$ $\left( \pm 0.3 \mathrm{Mm}^{3}\right)$. The results presented here outline the support of satellite data on tracking the evolution of volcanic activity and the importance to integrate satellite with ground-based geophysical data in improving assessments of volcanic hazard during eruptive crises.
\end{abstract}

Keywords: MODIS data; SENTINEL-2 images; infrasonic activity; open-vent activity; fissural eruption; long- and short-term precursors 


\section{Introduction}

Multidecadal satellite data from different platforms have provided great support for volcano monitoring, and are enlarging our knowledge on the processes that drive the eruptions (e.g., [1-5]). For example, infrared sensors with low to moderate spatial resolution (i.e., $>1 \mathrm{~km}$ ) make it possible to detect and quantify almost continuously the heat flux sourced from remote volcanoes [6,7], and may now be used to estimate, in near real-time, the lava discharged rates and erupted volumes, during worldwide effusive eruptions [5,8-10].The availability of high spatial resolution data (i.e., 30-90 m) acquired from different platforms constitutes a further improvement of space-based thermal volcano monitoring [11], making it possible to localize with high accuracy the position of an eruptive vents or, more generally, to characterize the thermal contribution of different volcanic sectors inferring magnitude and spatial information (e.g., location and size) of small hot spots (i.e., fumaroles, hot cracks) [12-15]. High-temporal resolution thermal data make it possible to track fast and energetic events (such as lava flows) once they have started $[9,10]$, but they not have sufficient spatial resolution to detect small and long-term precursory thermal anomalies.

On the other hand, ground-based monitoring networks, installed on active volcanoes, acquire, store and process several fundamental parameters (e.g., seismicity, infrasound) that, combined together, make a great contribution in the short-term forecasting of eruptive crises [16].

Open-vent basaltic volcanoes, such as Etna, continuously emit magmatic-related products into the atmosphere [17], and can be sporadically affected by more energetic phenomena, such as paroxysmal explosions or flank eruptions $[18,19]$ that can be preceded by short- or long-term precursors [20]. Hence, the ability to combine multiple dataset and to decipher the processes occurring within a volcanic system at different timescales represents a challenge and a future mandatory prerequisite for hazard assessment [21,22].

In this view, the great impact related to the explosive ash-rich paroxysms experienced by the Etna volcano in the latter years, pushed the scientific community to improve multiparametric monitoring systems by investigating long- and short-term variations in the behavior of the Etna volcano [23-26]. For example, Ripepe and coauthors [22] successfully developed a fully-automated early warning system that is able to track and notify the transition from violent intermittent strombolian activity to LFs- related eruptive column, based on infrasonic and thermal data [22].

In this work, we combine space- and ground-based geophysical data in order to investigate the September-December 2018 eruptive phase of the Etna volcano (Sicily, Italy), with a focus on the longand short-term precursor signals that preceded the main effusive event of the 24 December 2018, and the successive resuming of the summit explosive activity.

Heat flux data, derived by MODIS sensor, are used to calculate and track the evolution of time averaged lava discharge rates (TADRs) and erupted volumes, while the high-spatial resolution potentiality of SENTINEL-2 images are used to locate the thermal activity at the multiple summit active vents of Etna. Infrasonic arrays and tremor amplitude measures are used to track the intensity, the frequency and the source of the explosive events occurring at summit craters.

The integration of satellite and ground-based data, give us an in-depth ability to record the shifting from open-vent conditions, represented by sustained summit strombolian activity, to the 24-26 December flank effusion promoted by a 2-km long feeder-dyke intrusion. This approach is particularly useful for a complex and multiple-crater volcano as Etna, with composite eruptive pathway and high variability in distribution and impact of future opening vents and effusive fissures.

\section{Background}

Etna is an open-vent basaltic volcano, characterized by a persistent degassing and frequent explosive activity, ranging from low strombolian explosions to lava fountaining and sub-plinian ash-rich paroxysms [27-29]. This activity occurs at several active vents located at three main sectors of the summit area, named: Bocca Nuova-Voragine (BN/VOR, also cited as Central Craters-CC; [29]), NorthEast Crater (NEC) and Southeast Crater-New Southeast Crater (SEC/NSEC) ([30,31]; see Figure 1). 
This open-vent activity is periodically interrupted by effusive eruptions, occurring at the summit or along the flanks of the volcano, that drain portion of the shallow magmatic system of Etna [29,32-35]. While the so-called "summit eruptions" are fed by degassed magma likely stored at a shallow level and rising through an open central conduit [29], the flank and fissural eruption seems to be fed by a deeper, gas-rich magma. These eccentric eruptions take place along three main "rift zones"-NE Rift, S Rift and W Rift-outlining the strict control played by the tectonic structural framework of the volcano on the opening of lateral vents $[34,36]$. The eccentric flank eruptions may be promoted by magma reaching the surface via new, secondary conduits and/or dike intrusions, successively being erupted from propagating lateral fissures with multiple aligned vents $[29,36]$. In this view, a main hazard source at the Etna volcano is related to the opening of distal eruptive fissures with lava flows that potentially threatened nearby villages, infrastructures and tourist facilities [37].

During the last decade, the Etna volcano has exhibited a migration in persistence and magnitude of eruptive activity from SEC toward the NSEC crater, due to a preferential NE-SW oriented dilatation in the summit sector promoted by NE volcano flank instability during inflation phases [38]. Since 2011, its activity has been characterized by the occurrence of several (54) Lava Fountain (LF) episodes occurring at NSEC and VOR, generally preceded by an hour- to day-long increase of strombolian activity $[22,25,29,39]$, and recurrently accompanied by short-lived $(0.5-9 \mathrm{~h})$, low-volume $\left(0.5-3 \mathrm{Mm}^{3}\right)$ lava flows. The 2011-2018 period was also characterized by 5 minor effusive eruptions (January-April 2014, July-August 2014, February 2017, March-April 2017, August 2018) not accompanied by lava fountain activity [40,41]. These events were characterized by duration from 5 to 75 days, and by limited erupted volumes (between 1 and $12 \mathrm{Mm}^{3}$; [42-45],) remarking a clear difference from the voluminous eruptions occurred between 2001-2009 (having duration of 20-420 days and volumes of 30-60 $\mathrm{Mm}^{3}$; [46]).

The last effusive episodes occurred on 24 December 2018, and were characterized by the opening of an eruptive fissure at the base of the New South-East Crater on the western flank of Valle del Bove. The eruption produced gas and ash-rich plumes from the summit vents an intense Strombolian activity along the fissure, feeding several eastward lava flows [47]. Notably, this event was accompanied by an intense seismic swarm (more than 130 earthquakes in $3 \mathrm{~h}$ ) culminating, on 26 December at 2:19 am (UTC), with a Mw 4.9 earthquake with the epicenter between the village of Lavinaio and Viagrande (CT), in correspondence of the Flandaca Fault. The earthquake was very shallow (1.2 km depth) and affected buildings, facilities and injured a dozen of people close to the epicentral areas along the lower south-eastern flank of Etna [48]. 

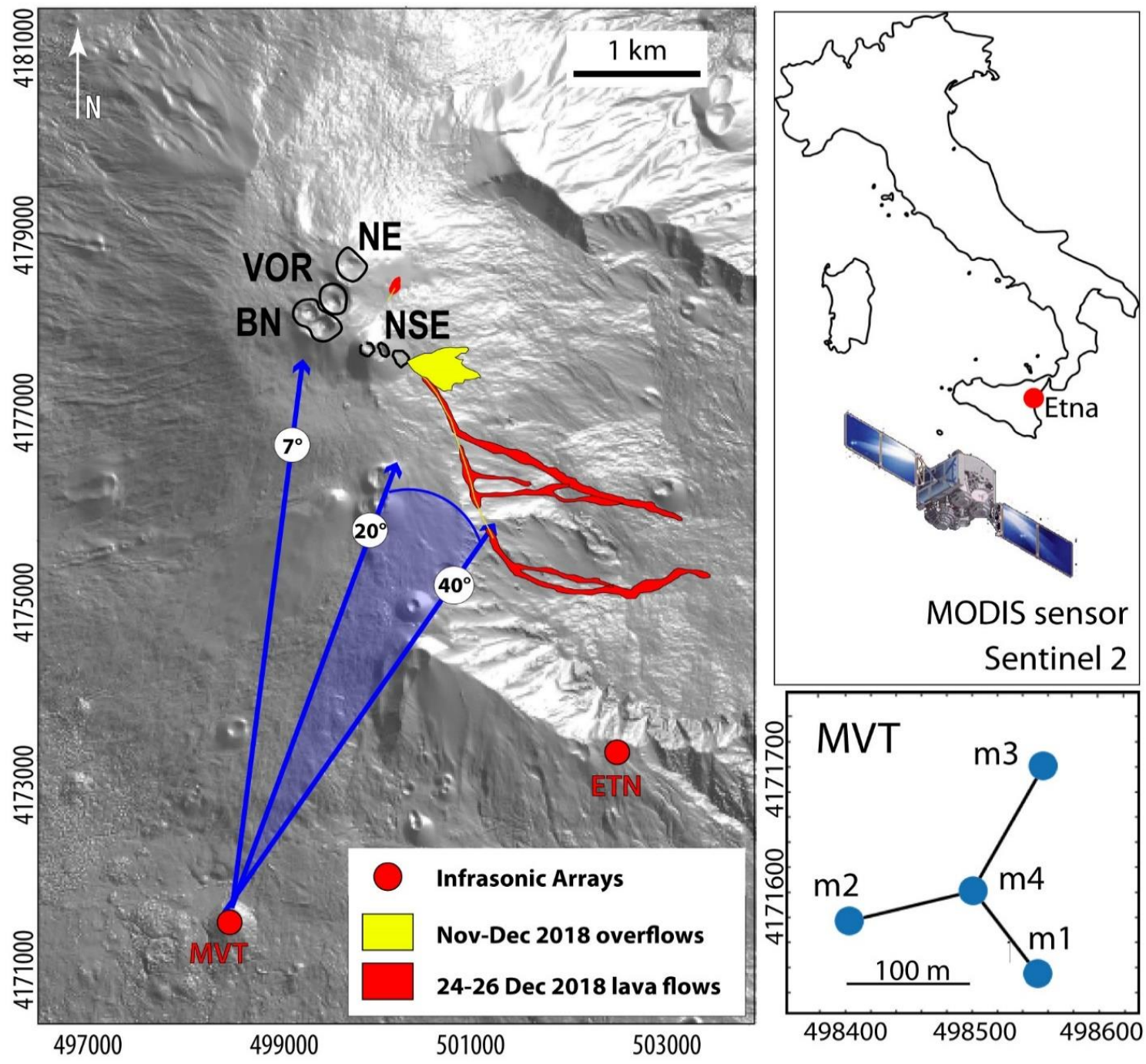

Figure 1. Shaded relief map of Etna summit area, with the indication of the main crater sectors and approximate maps of lava flows emplaced during the September-December 2018 activity. The location and the configuration of the MVT infrasonic array are also represented (see Method section). Blue arrows show the main localized back-azimuth during summit $\left(7^{\circ}, \mathrm{BN} / \mathrm{VOR}\right.$ sector $)$ and lateral activity $\left(20^{\circ}-40^{\circ}\right.$, eruptive fissure), respectively. The adopted satellite sensors are also presented.

\section{Dataset and Methods}

Our work is based on the analysis of 2 satellite-based thermal datasets (provided by MODIS and SENTINEL 2 sensors, respectively) and 2 geophysical datasets, constituted by seismic and infrasonic signals recorded at ETN and MVT stations, respectively (Figure 1). Here, we summarize the methodology used to analyze these four sets of data in order to track the activity of the Etna volcano occurred between September and December 2018.

\subsection{Volcanic Radiative Power by Using MODIS-MIROVA Data}

MIROVA is a fully automatic volcano-dedicated hot-spot detection system ([49]) based on the images acquired by the MODIS sensor mounted on TERRA and AQUA NASA's satellites.

The combination of spatial and spectral principles to the middle infrared images acquired by MODIS makes possible the identification of the hot-spot contaminated pixel(s) (1 km resolution) and, 
consequently, the quantification of high temperature $(>600 \mathrm{~K})$ thermal anomalies, in terms of Volcanic Radiative Power (VRP, in Watt) (see [50]). The VRP (in Watt) is calculated through the MIR-method [50]:

$$
\mathrm{VRP}_{\mathrm{pIX}}=\mathrm{A}_{\mathrm{pIX}} \times 18.7 \times\left(\mathrm{L}_{4 a l e r t}-\mathrm{L}_{4 \mathrm{bk}}\right)
$$

where $A_{\text {Pix }}, L_{4 a l e r t}$ and $L_{4 b k}$ are the pixel area $\left(10^{6} \mathrm{~m}^{2}\right.$ for MODIS), and the middle infrared radiance (W $\mathrm{m}^{-2} \mathrm{sr}^{-1} \mu \mathrm{m}^{-1}$ ) recorded by the alerted $\left(\mathrm{L}_{4 \text { alert }}\right.$ ) and background $\left(\mathrm{L}_{4 \mathrm{bk}}\right)$ pixels, respectively. According to [50] for hot targets that have an integrated temperature comprised between 600 and $1500 \mathrm{~K}$, the use of the constant of $18.7 \mathrm{sr} \cdot \mu \mathrm{m}$ provides reliable estimates of radiant power with an uncertainty of $\pm 30 \%$. This makes VRP particularly appropriate for calculating the heat flux sourced by only the active portions of lava flows, being almost insensitive to cooling lava surfaces having temperature lower than $\sim 300{ }^{\circ} \mathrm{C}$ [49].

Overall, during the September 2018-January 2019 period, MIROVA elaborated more than 657 images (four overpasses per day) of which 184 (ca. 28\%) detected a thermal anomaly. The VRP values range from less than $1 \mathrm{MW}$ to a maximum of $2295 \mathrm{MW}$, this last being recorded on December 24 at 21:15 UTC.

\subsection{Time Average Discharge Rate and Erupted Volume via MODIS Data}

Satellite thermal data represent a useful parameter to estimate of Time Averaged lava Discharge Rate (TADR) and erupted volumes during effusive eruptions [51]. This thermal approach relies on the observed relationships that characterize the effusion rates, the active flow area, and the thermal flux, as documented by [51-54].

Here, we adopted an empirical approach, proposed by [55], that directly relates the volcanic radiant power (VRP), measured via MODIS, to the Time Average Discharge Rate (TADR) through a unique, best-fit parameter, called radiant density $\left(\mathrm{c}_{\mathrm{rad}}\right.$; in $\left.\mathrm{J} \mathrm{m}^{-3}\right)$;

$$
\mathrm{TADR}=\frac{\mathrm{VRP}}{\mathrm{c}_{\mathrm{rad}}}
$$

This empirical parameter represents the bulk efficiency of the lava body to radiate heat from its active surface, and is mainly controlled by the rheological, insulation, and topographic conditions at the time of emplacement $[49,55]$. Consequently, by integrating VRP measurements in time to obtain the total Radiant Energy (VRE) we are able, to estimate the erupted volume by assuming the appropriate $\mathrm{C}_{\mathrm{rad}}$, for the observed lava flow.

Based on previous calibration of the radiant density typical of Etnean lava flows [49,55], here we used a $c_{\text {rad }}$ between 2 and $3.6 \times 10^{8} \mathrm{~J} \mathrm{~m}^{-3}$ that makes it possible to constrain the erupted lava volumes between a minimum and maximum value.

It should be noted that the above method relies on the assumption that all the heat recorded by space is produced by the outpoured lava from the surface and the emplacing of lava flow or lava body. However, during open-vent activity, no net lava can be outpoured from the volcano, despite a thermal anomaly is still detected. In these cases the thermal approach can be used to infer the rate at which magma reaches the uppermost levels of the conduit (i.e., the bottom of a crater), before being cycled back in the convective magma column [56-59]. In this view, a variation in magnitude and persistence of heat radiation from summit craters could indicate a different level of magma column [60].

\subsection{SENTINEL 2 Images}

The Multispectral Instrument (MSI) is carried on-board SENTINEL-2A/2B platforms, two ESA satellites launched on polar, sun-syncronous orbit on June 2015 and March 2017, respectively. MSI provides multispectral data in 13 bands from VNIR to SWIR spectral region, useful for volcano monitoring applications. Indeed, the $20 \mathrm{~m} /$ pixel high-spatial resolution in the SWIR bands makes it 
possible to detail morphometric thermal features of the heat volcanic sources and distinguish active volcanic craters, or sectors, during ongoing eruptions (with a decameter spatial detail; [14,42]).

The SENTINEL-2 data are made available by the ESA Copernicus Service Data Hub (https: //cophub.copernicus.eu/dhus/\#/home), were downloaded through the cloud storage service of Amazon Web Service S3 (AWS-S3, https://registry.opendata.aws/SENTINEL-2/). Over the Etna geographical area, SENTINEL-2 satellites have a revisit time of about 2-3 days considering the two inspecting platforms $2 \mathrm{~A}$ and $2 \mathrm{~B}$, enabling us to acquire about 10 high-resolution images per month, on average.

Following Massimetti et al. [61] we used the TOA (Top of the Atmosphere) reflectance data with a band combination 12-11-8a in the SWIR spectral region (R: $2190 \mathrm{~nm}, \rho 12 ; \mathrm{G}: 1610 \mathrm{~nm}, \rho 11$; B: $865 \mathrm{~nm}, \rho 8 \mathrm{a})$.

To analyze the thermal signature and to enlighten the presence of hot-spots, we applied a simple approach based on spectral ratios analysis of 12-11-8a bands, detecting and locating the number of "hot" pixels for each image in which a thermal volcanic emission is ongoing [62]. The algorithm to detect hot-spot contaminated pixel applied here was already successfully tested on several worldwide volcanic targets in comparison with MODIS-MIROVA heat flux [61]. For each pixel detected as "hot", we calculated a Thermal Index (T.I.) as the sum of the reflectances in the three SWIR bands analyzed (e.g., T.I. $=\rho_{12}+\rho_{11}+\rho_{8 \mathrm{~A}}$ ) which is here considered as a proxy of the heat source temperature. We use the Thermal Index map to create stacked thermal profiles over the summit crater area of the Etna volcano (Figure 4), enabling us to distinguish the different craters in terms of persistence and to quantify the thermal contribute of each defined sector (see section Results).

To summarize, the SENTINEL-2 data are used to:

- observe qualitatively the ongoing eruptive state, comparing the chronology of Etna activity with the visual inspection of satellite images;

- track the thermal activity of each summit crater sector via the number of "hot" pixels detected during September-December 2018;

- evaluate the area and the length of the lava body produced during the analyzed timespan by image processing.

\subsection{Infrasound Arrays and Seismic Tremor}

Infrasound monitoring at the Etna volcano is performed with two 4 elements small aperture infrasound arrays [22,63,64], named ETN and MVT and installed, respectively, on September 2007 and in 2015. The ETN array was installed at $2100 \mathrm{~m}$ a.s.l., at a distance of $5500 \mathrm{~m}$ from the summit craters on the southern rim of Valle del Bove, while the MVT was installed on the southern flank of volcano at $1800 \mathrm{~m}$ a.s.l. and at a distance of about $6500 \mathrm{~m}$ from the craters. Both arrays are equipped with a FIBRA (www.item-geophysics.it) with four elements deployed following a triangular geometry and with an aperture (maximum distance between two array elements) of $\sim 250 \mathrm{~m}$ and $\sim 150 \mathrm{~m}$, respectively ([22]; see Figure 1). Each array element is equipped with a differential pressure transducer with a sensitivity of $25 \mathrm{mV} / \mathrm{Pa}$, maximum pressure range of $\pm 100 \mathrm{~Pa}$, and flat frequency response between 0.01 and $100 \mathrm{~Hz}$. Infrasound pressure data are converted to digital at each array element, transmitted with fiber optic cable to the central array element, where data is collected and GPS time stamped. The use of fiber optic made it possible to increase the signal-to-noise ratio and reducing the damages related to lightning and electrical discharges, with the ETN array being operational continuously since 2007. At ETN the array is co-located with a Guralp CMG-6T broadband seismometer, with eigen-period of $10 \mathrm{~s}$ and sensitivity of $2000 \mathrm{~V} / \mathrm{m} \mathrm{s}^{-1}$.

Infrasound array data are processed in the time domain by applying a grid search procedure for a source within the crater area. The analysis is applied on 5-s-long time window. The sound speed velocity is fixed within the $330-360 \mathrm{~m} \mathrm{~s}^{-1}$ apparent velocity range, which accounts for a temperature effect on the acoustic propagation velocity and for the source-receiver elevation differences $(1300 \pm 100 \mathrm{~m}$ for the ETN array and $1600 \pm 100 \mathrm{~m}$ for the MVT array). These two constraints allow the automatic removal of all the sources different from the volcano. The algorithm ([65,66] for details) 
searches for coherent signals recorded across the array, and we define a detection when the semblance exceeds 0.5. For each detection, the corresponding back-azimuth and the mean acoustic pressure are thus calculated according to the delay times observed among the different channels. Considering the aperture of the two arrays $(<250 \mathrm{~m})$ and the typical frequency of $1 \mathrm{~Hz}$, the expected azimuth resolution is $\sim 2^{\circ}$ [67], which corresponds to $\sim 190-230 \mathrm{~m}$ horizontal resolution at a source-to-receiver distance of $5500-6500 \mathrm{~m}$. This processing is applied to the infrasonic data recorded at both the ETN and MVT arrays.

Here, we analyze the MVT array data because its capability, due to the location (Figure 1), to discriminate between Central Craters (BN/VOR and NE) and SE (NSE and SE) explosive activity.

\section{Results}

The complete time-series of the parameters recorded during September- December 2018 is shown in Figure 2. Based on our acquired datasets, inspection of satellite images and published reports (www.ingv.it), we subdivide the analyzed period into five main phases:

1. 1 September-4 November 2018; characterized by a monthly-long phase characterized by a low-level explosive activity at summit vents;

2. 5-28 November 2018; characterized by a gradual increase in explosive activity at summit vents;

3. 29 November-23 December 2018; characterized by the concurrent strombolian and overflows activity at BN vents and NSE sector, respectively;

4. 24-26 December 2018; the 24 December short-live lateral effusive episode along an NNW-SSE oriented $2 \mathrm{~km}$-long eruptive fissure;

5. 27 December 2018-15 January 2019; the resumption of a highly-energetic explosive activity, localized at Central Craters sector, overlapping the end of the fissural effusive phase.

\subsection{Phase I (1 September-4 November 2018): Low-Level Explosive Activity at Summit Craters}

After the short effusive eruption of 23-29 August 2018 a low activity persisted at the Etna volcano from September to mid-November (Phase I; Figure 2). This period was characterized by persistent degassing, and low-level strombolian activity at the Central Craters (www.ct.ingv.it). Thermal and geophysical observations during this phase outlined: (i) sporadic low to moderated MODIS-MIROVA thermal alerts (VRP < $20 \mathrm{MW}$; Figure 2a); (ii) tremor amplitude at background level (Figure 2b) and (iii) low-pressure infrasonic detections ( $<1 \mathrm{~Pa}$ at MVT array; Figure $2 \mathrm{c}$ ) localized at the BN crater (back-azimuth about $7^{\circ}$ ). In particular, SENTINEL-2 images show that the MODIS-detected thermal alerts were sourced by two distinct vents hosted within BN crater and from NSE sector with a sustained degassing from NE and Central Craters (Figure $3 a-c$ ). 

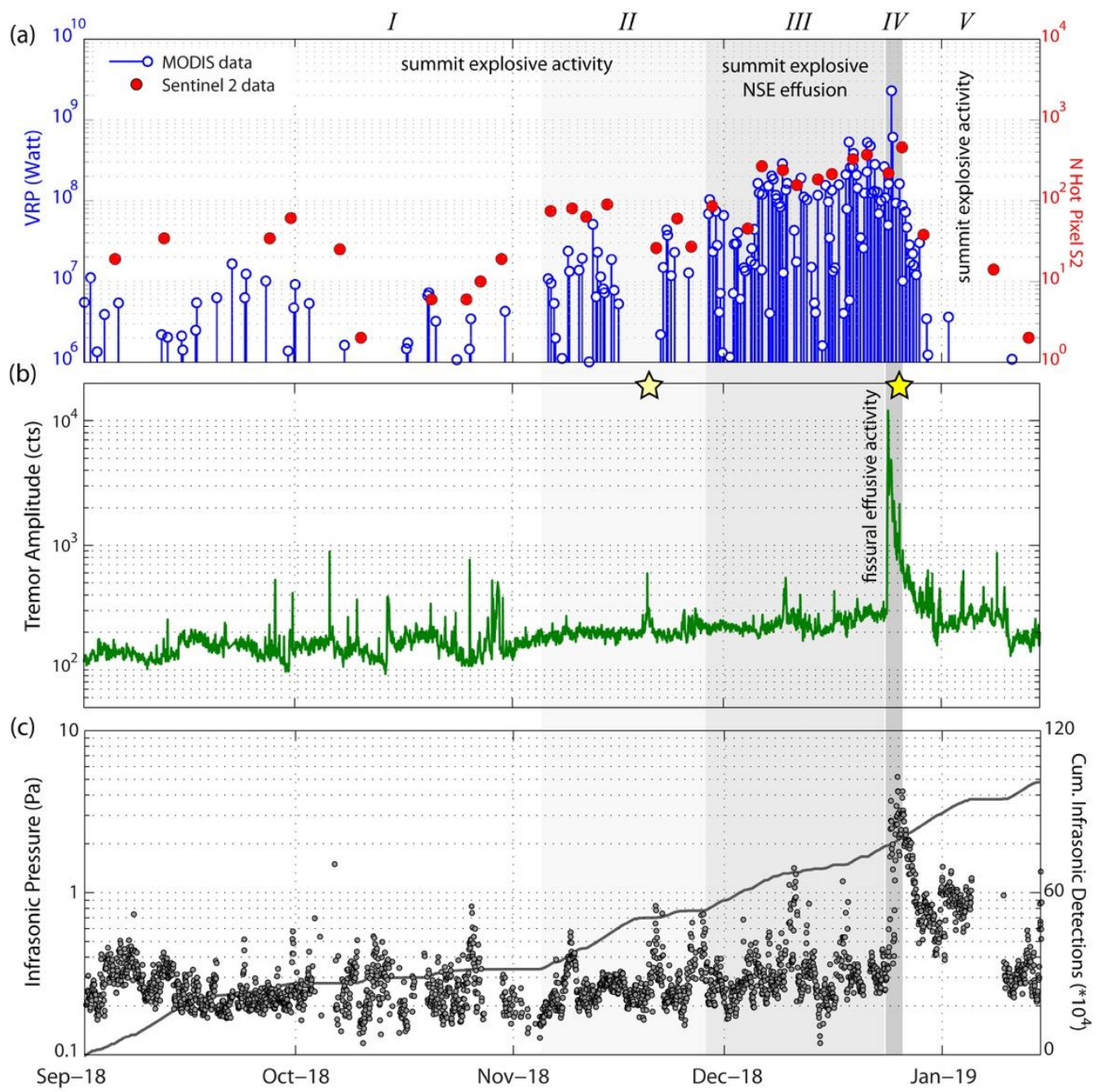

Figure 2. 1 September 2018 -15 January 2019 time-series of thermal, seismic and infrasonic activity at the Etna volcano: (a) VRP (blue stem) and Number of Hot Pixel (red circles) as retrieved by MODIS-MIROVA and SENTINEL-2 images, respectively; (b) hourly-mean tremor amplitude expressed as RSAM measured at ETN station; (c) hourly-mean amplitude pressure of the infrasonic detections recorded at MVT array (see Figure 1) and cumulative number of detections at the same array. See Figure 1 for ETN and MVT location. All datasets are expressed as logarithmic scale, excepted for the Number of Infrasonic detections. Yellow stars represent the occurrence of the 20 November seismic swarm and the 26 December earthquake $(\mathrm{Mw}=4.9)$, see text for details. 


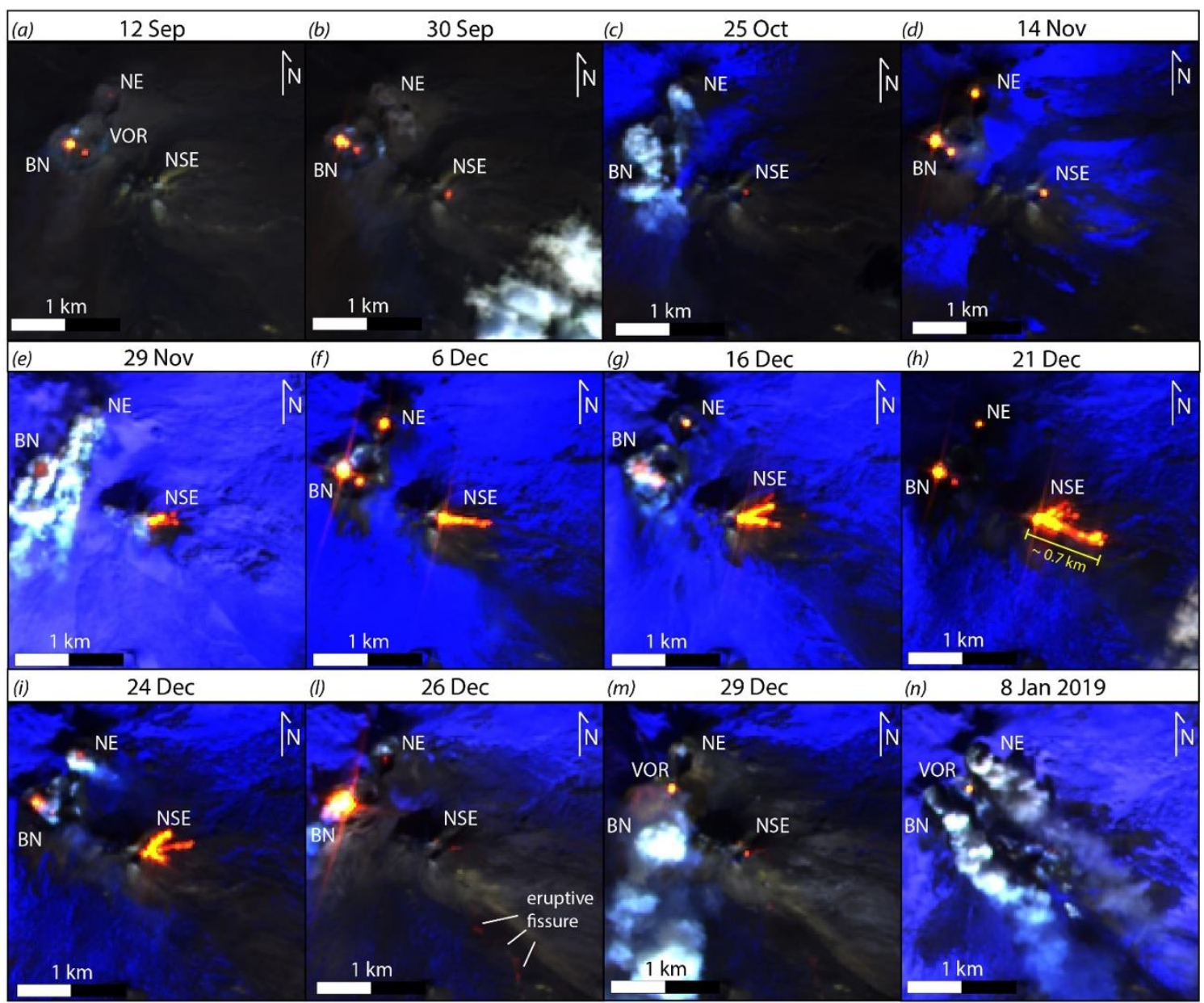

Figure 3. SENTINEL-2 class images acquired during the investigated Etna activity, in with summit craters are marked. The imagery is processed in RGB colors (bands 12-11-8a) to enhance the presence of hot targets (see Method section). Images represents the most representative shots (a-n) of the activity characterized Etna volcano during September-December 2018 period.

\subsection{Phase II (5 November-28 November 2018): Gradual Increase in Explosive Activity at Summit Craters}

Since early November, an intensification on summit thermal activity at NSE and NE craters was tracked by high-spatial resolution SENTINEL-2 images (Figure 3d). A clear increase in the number of hot pixels (Figure 2a) was in fact coupled with a VRP that reached a value above $50 \mathrm{MW}$, for the first time on 12 November, (see Figures $2 \mathrm{a}$ and $3 \mathrm{~d}$ ). This thermal increasing trend was confirmed by an increment in clustered medium infrasonic pressure transient (up to $1 \mathrm{~Pa}$ at MVT array; Figure 2c) associated to strombolian explosions. On 20 November 2018, a 15 h-long seismic swarm affected the western sector of the volcano [68].

\subsection{Phase III (29 November-24 December 2018): Strombolian and Effusive Activity at Summit Craters}

A few days after the seismic swarm of 20 November, the Etna volcano showed a further increase of summit activity, with the beginning of a sporadic lava effusion from a vent opened at the eastern base of the NSE crater. SENTINEL-2 images firstly captured this overflow activity on 29 November (see Figure 3e) when emissions become more continuous. Similarly, on 29 November at 00:50 UTC, MODIS data firstly record VRP value above $100 \mathrm{MW}$ (Figure 2a). This marked change in the thermal activity detected by space marks the transition from Phase II to Phase III. Satellite observations tracked the persistence of the lava overflows from the NSE Crater producing short lava flows towards East-South East direction (maximum length of ca. 0.7 km, i.e., 21 December; Figure 3e-h). 
Overall, MODIS thermal alerts during December 2018 show a significant augmentation in terms of both frequency (from 15\% to 75\% of the overpass) and intensity (from 25 to $160 \mathrm{MW}$, on average). The further increase in VRP measured since 18 December (above the $200 \mathrm{MW}$; Figure 2a), corresponds to the occurrence of several lava flows outpouring from the vent(s) at the base of the NSE crater, as reported by field observations [69]. This heat flux increment is coherent with a general increase in the number of hot pixels detected by SENTINEL-2 images during the same period (Figure 2a).

In the Phase III, the effusive episodes at NSE was accompanied by the concurrent explosive activity at $\mathrm{BN}$ and NE craters (Figure 3e-h). This is also outlined by the increased thermal anomalies detected by thermal profiles obtained by SENTINEL-2 Thermal Index map processing (Figure $4 a, b$ ). Despite of a sustained activity at the others summit craters, no thermal anomalies were detected inside VOR throughout Phase I, II and III (Figures 3e-h and 4a,b). It is worth noting that the overall heightened eruptive activity at the summit craters was accompanied by only a moderate increase in frequency and amplitude of infrasonic detections (Figure 2b).

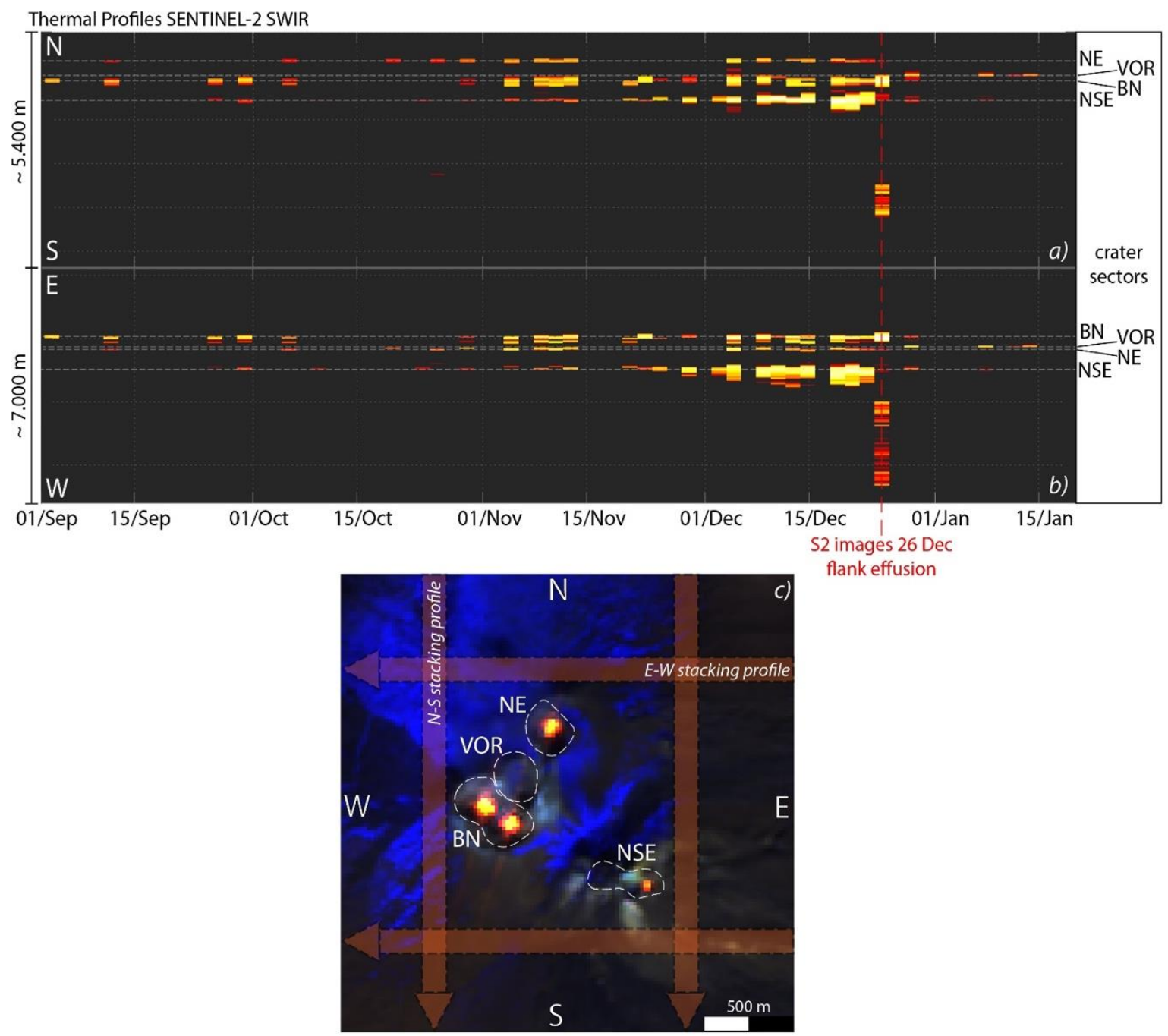

Figure 4. N-S and E-W thermal profile(s) acquired at summit crater sector of the Etna volcano during September 2018- January 2019 (a,b). The profiles are produced stacking each SENTINEL-2 image, analyzed in the SWIR bands and with at least one hot pixel anomaly, in two direction, from north to south (for each row) and from east to west (for each column; (c)). With white dotted lines are marked the Etna craters locations, thus letting to enlighten the presence of thermal activity over time for each vent(s). The hot pixel spread toward south and west in both profiles (red sign) indicate the occurrence of eruptive fissure feeding the lava flow of the 24 December. 


\subsection{Phase IV (24 December-26 December 2018): Opening of Lateral Fissure and Distal Effusive Activity}

The general increase of eruptive activity recorded during the Phases II and III culminated on 24 December when the geophysical network recorded a drastic change on infrasonic and seismic signals (Figure 5). At 06:00 UTC there was a sudden, almost complete cessation of infrasonic activity at the Central Craters (back-azimuth close to $7^{\circ}$; see Figures 1 and 5b), followed at 08:24 UTC, by a sharp increase in volcanic tremor (Figure 5a,c). Intense grey- and reddish-ash plumes were observed from NE and BN craters [47] and accompanied the rapid rise of the tremor amplitude that reached a peak value at about the 11:00 UTC (Figure 5c). Hence, the volcanic tremor started to decline, while infrasonic activity resumed, but with back-azimuth consistent with a new source, located at SE from the summit craters (back-azimuth spanning from $20^{\circ}$ to $40^{\circ}$ angle; see Figure $5 \mathrm{~b}$ ). During this period, ground surveys reported the opening of a $2 \mathrm{~km}$-long NNW-SSE eruptive fissure (EF) extending from the south-east base of the NSE crater, (at $3000 \mathrm{~m}$ a.s.1.) toward the upper portions of the west rim walls of the Valle del Bove (2400 m a.s.1.) [47]; cf. Figures 1 and 6). This episode was accompanied by violent strombolian explosions and ash emissions from distinct fissure segments, as well as by the emission of several lava flows units descending along the steep walls of the Valle del Bove [47]. The end of fissure propagation was marked by a new, sharp shift of infrasonic detections that, since 13:00 UTC were localized again at BN crater (Figure 5). However, SENTINEL-2 and MODIS images acquired, at 10:00 UTC and 11:50 UTC, respectively, did not show yet any clear increase in terms of intensity and extension of thermal anomaly at the summit craters, still indicating the occurrence of a multiple-branch overflow from NSE sector (Figures 5 and 6a). Interestingly, the SENTINEL-2 image shows a dark-grey plume, apparently sourced at the base of northwards side of Serra Giannicola Grande (Figure 6a), that could be possibly associated to a landslide generated in response to the ongoing fissure propagation and/or related to the intense seismic activity. On the evening of 24 December, at the 21:15 UTC, the MODIS image recorded a peak value of 2294 MW suggesting that an important effusive activity was ongoing (Figure 2a). However, the successive image, acquired just few hours later at 01:25 UTC of 25 December, detected a much lower thermal radiation (612 MW), likely resulting from a rapidly waning phase of lava emission. The decrease of thermal activity was, in turn, accompanied by a marked return of intense explosive activity at the Central Craters, as outlined by the infrasonic pressure measured at MVT array (Figure 5a). In particular, the peaking period of explosive activity recorded at BN sector on 25 December at 12:00 UTC (with infrasonic pressure up to $15 \mathrm{~Pa}$ ) was coupled by VRP values close to $100 \mathrm{MW}$, suggesting that the feeding of lateral lava flow was drastically decreased or, at least, ceased.

The end of the lateral eruption was accompanied by the closure of the effusive crack, and by the reactivation of the explosive activity at the summit vents, as clearly testified by the SENTINEL-2 image acquired on 26 December at 10:00 UTC (see Figure 6b). This image captured the cooling of the southernmost lava flow unit (about $2.5 \mathrm{~km}$ in length), as well as a clear thermal anomaly at BN that, outline a sudden resumption of explosive activity at the summit craters (Figures $5 \mathrm{~b}$ and $6 \mathrm{~b}$ ), as supported by infrasound detections.

Notably, during the ongoing eruption, at 02:19 UTC on 26 December, an earthquake of Mw 4.9 localized on the SE flank of the volcano and linked to the reactivation of the Fiandaca Fault, injured 28 people and damaged several buildings in the villages surrounding the fault [70]. 

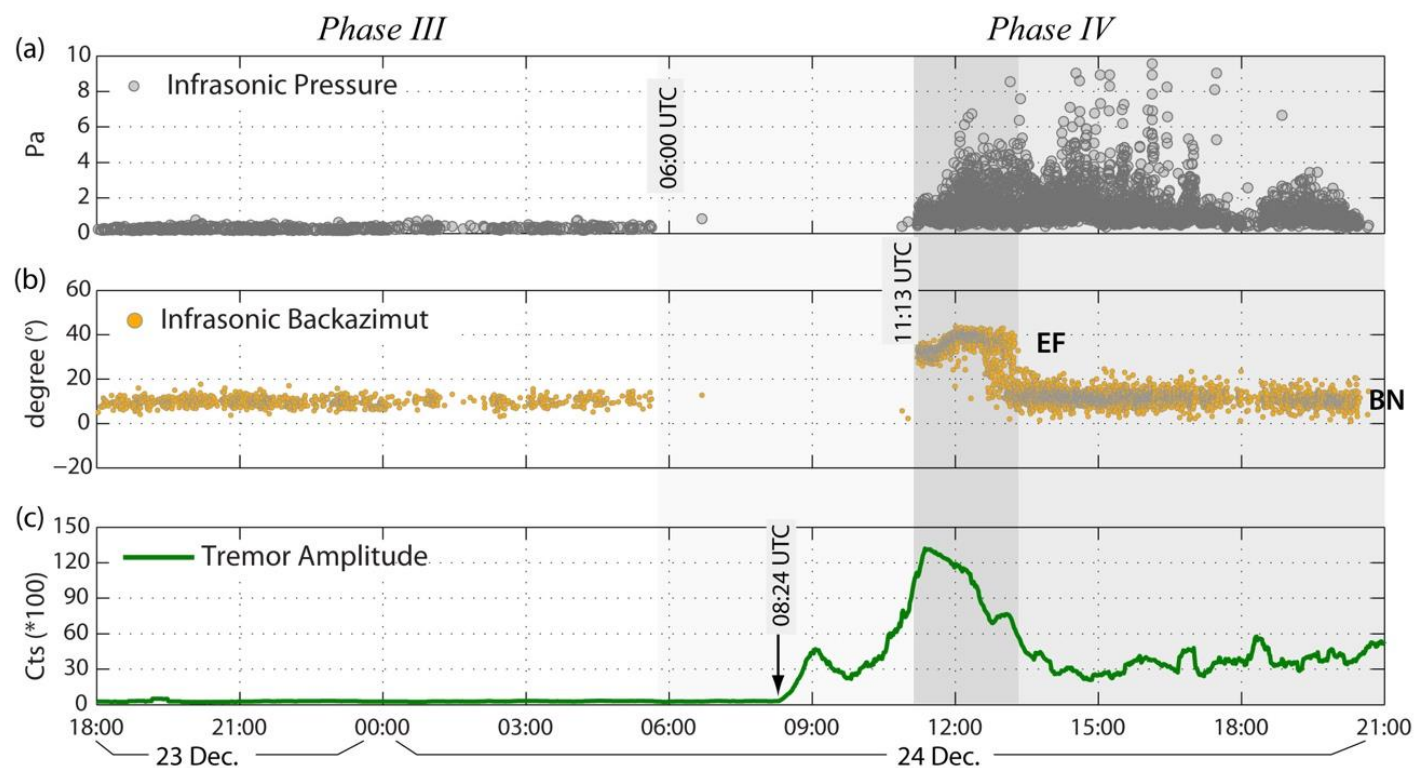

Figure 5. Timeseries of the 23-24 December of: (a) amplitude of infrasonic detections; (b) direction of the infrasound activity, EF-eruptive fissure; BN-Bocca Nuova; (c) tremor amplitude recorded at ETN site. (a) and (b) are those recorded at MVT, see Figure 1 for location of ETN and MVT sites.

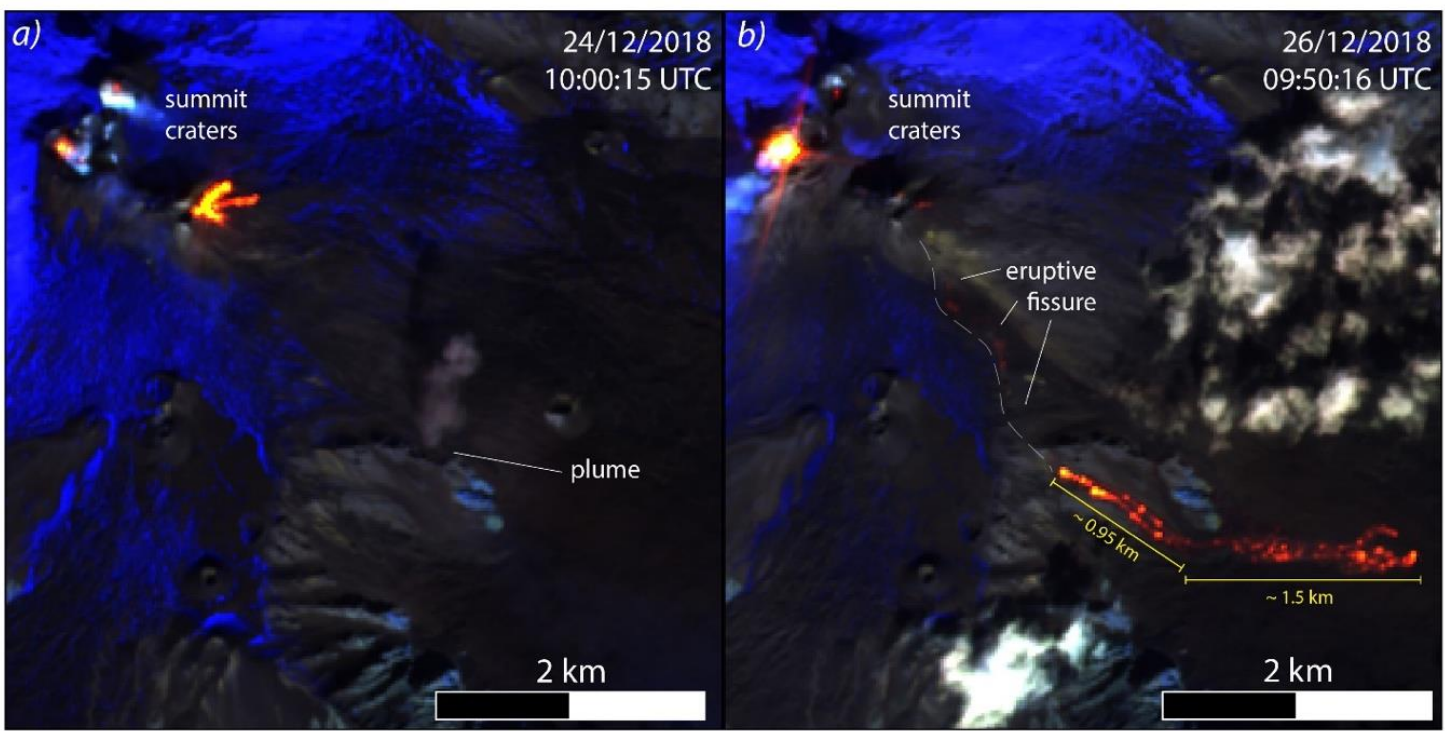

Figure 6. Focus on 24 (a) and 26 (b) December 2018, Phase III of the Etna volcano activity. SENTINEL-2 class images are processed in RGB colors (bands 12-11-8a), and to enhance the presence of hot targets (see Method section). The images resume the eastern summit portion of Etna edifice, covering from craters area to the upper portion of Valle of the Bove.

\subsection{Phase V (26 December 2018-15 January 2019): Summit Explosive Activity}

The end of the short-lived lateral effusion was followed by an intense and powerful explosive activity mainly localized at BN/VOR sector as recorded by the integrated geophysical measurements and supported by space-based thermal data. The thermal output detected by MODIS-MIROVA persisted at moderate levels (10-100 MW), as typical of high-explosive summit activity, while the SENTINEL-2 images make it possible to confine thermal anomalies within the Central crater sector, showing an extensive and intense anomaly rising from BN sector (Figure 31,m). Moreover, since 29 December, the VOR crater was "thermally reactivated", as shown in Figure 31 and in the thermal profiles (Figure 4a,b) retrieved by high-resolution images. Since early January 2019 all the monitored 
parameters suggest a general decrease and a return to moderate explosive and sustained degassing activity, particularly from BN and NE craters (Figures 2 and 3m,n).

\section{Discussion}

The datasets presented in the previous chapter outline the variations of thermal, infrasonic and seismic activity continuously monitored at the Etna volcano by space- and ground-based sensors. The trends preceding and following the 24 December fissural eruption are well represented by plotting the cumulative curves of the above-mentioned parameters as recorded by SENTINEL 2 images, MVT infrasonic array and ETN seismic station, respectively (Figure 7).

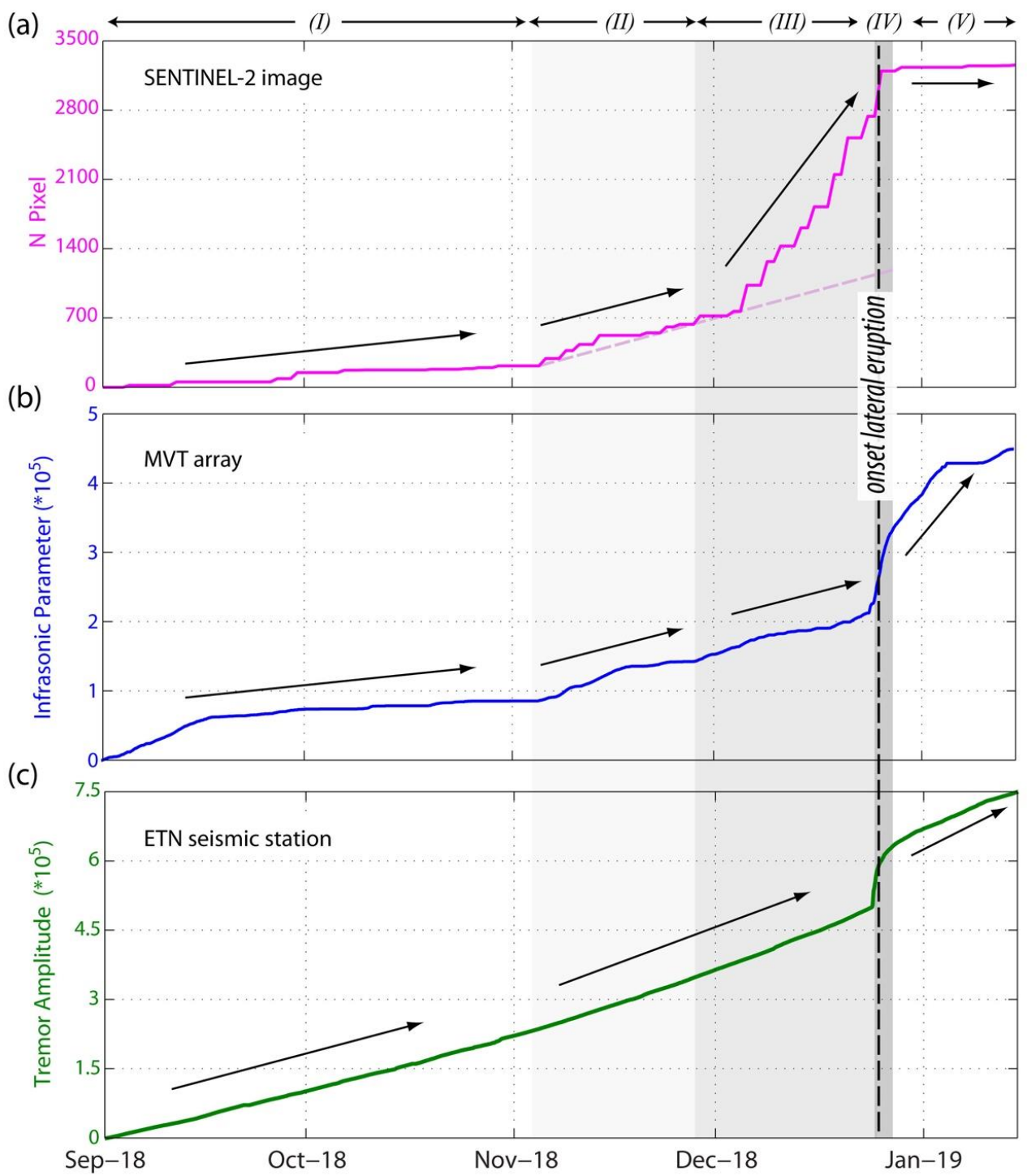

Figure 7. Cumulative trend of: (a) number of hot-detected pixels retrieved by SENTINEL-2 images, (b) the number of hourly infrasonic detection multiplied per the hourly-average infrasonic pressure of the detected events, and (c) the hourly-mean seismic tremor amplitude counts In the Phase II the increasing of explosive activity marked by infrasonic measures was accompanied by a similar trend in thermal behavior track by SENTINEL-2 images. During the Phase III the thermal activity show a clear increase related to the NSE overflow episodes that cause the separation in infrasonic and thermal signals. In (a) the grey dotted line highlights the hypothetical contribution of explosive activity on the whole thermal activity following the infrasonic activity. Black dotted vertical line marks the onset of the lateral effusive activity as recorded by the seismic tremor amplitude. 
Firstly, it can be noted that the increase in thermal activity at the end of November 2018 (Phase III in Figure 7a), was preceded by a slight increment in both thermal and infrasonic activity started since early November 2018 (Phase II; Figure 7a,b). Notably, SENTINEL 2 images allowed us to recognize the contribution of two distinct thermal sources: (i) the overflows at the eastern base of the NSE crater; (ii) the Strombolian activity localized at BN, NE and NSE vents. In contrast, the cumulate in tremor amplitude highlights that before the sharp increase preceding the 24 December event, seismic tremor stays at background level and showing any significant variations during September-November timespan (Figure 7c).

In our view, the occurrence of strombolian and outflows activity at different summit craters, coupled by sustained and growing infrasonic activity, likely represented the surface expression of a slow but continuous increase in the magma supply within the shallow portion of the magma column.

In fact, by considering Time Averaged Discharge Rates (TADR, retrieved by MODIS heat flux; see Method Section), the Phase III was characterized by an overall value of $0.5-0.9 \mathrm{~m}^{3} \mathrm{~s}^{-1}$, for a total volume outpoured during the summit overflow episodes of $0.9-1.7 \mathrm{Mm}^{3}$ (Figure 8). On a whole, the ongoing summit effusive regime in relation with the increase in thermal flux, seems to indicate a value of $100 \mathrm{MW}\left(0.3-0.5 \mathrm{~m}^{3} \mathrm{~s}^{-1}\right)$, as a possible threshold for the transition between open-vent conditions to effusive activity, as already suggested by Coppola et al. [57].

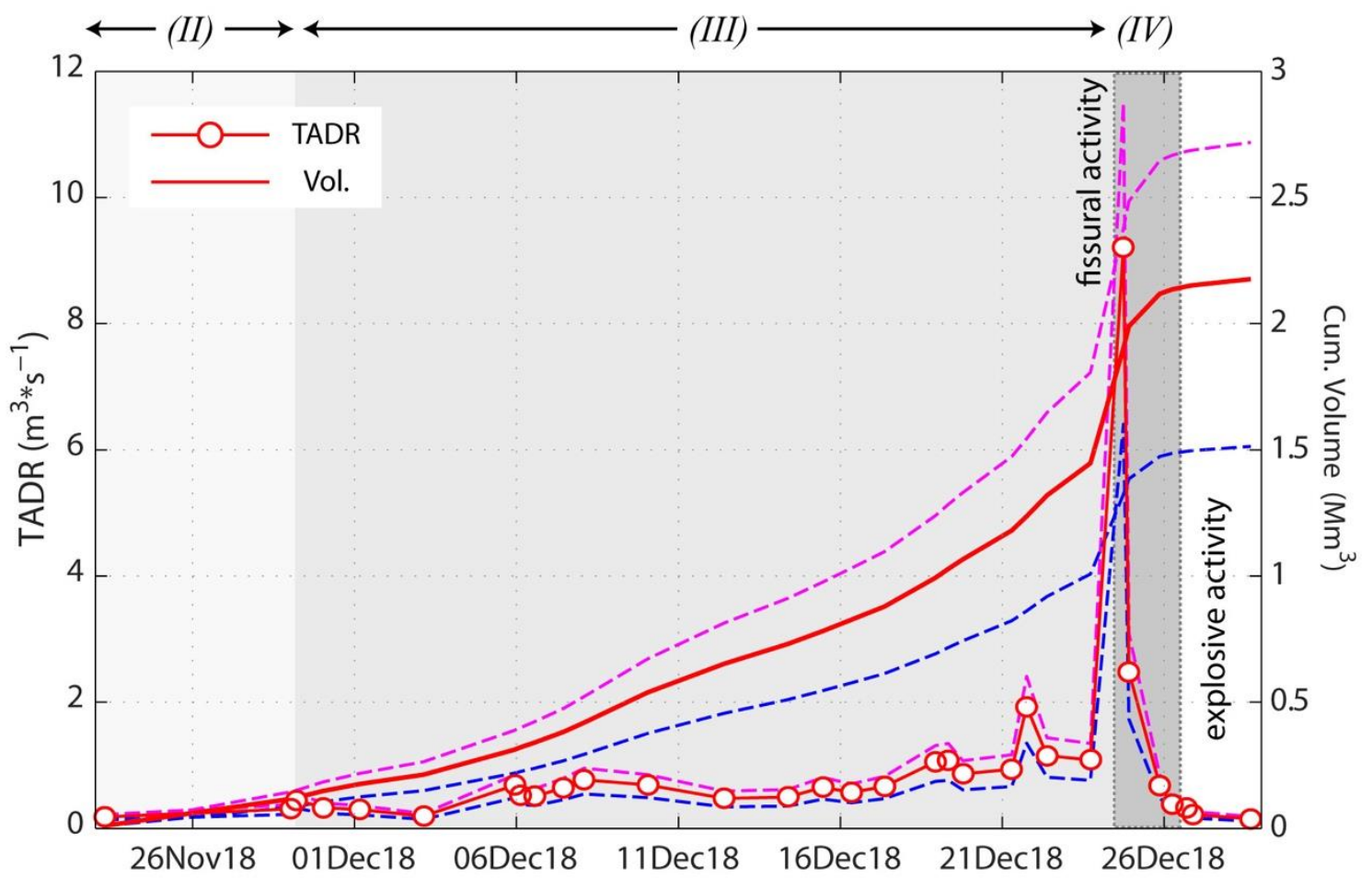

Figure 8. TADR and Volume trend retrieved from MODIS data, measured during the effusive phase experienced by Mt. Etna on November-December 2018 by using a proposed $\mathrm{c}_{\mathrm{rad}}$ of $2.5 \times 108 \mathrm{~J} \mathrm{m-3}$. Blue and magenta dotted lines represent ranging estimates of plotted parameters as obtained by $\mathrm{c}_{\mathrm{rad}}$ equal to $2 \times 10^{8} \mathrm{~J} \mathrm{~m}-^{3}$ and $3.6 \times 10^{8} \mathrm{~J} \mathrm{~m}-^{3}$, respectively (see Method section).

On 24 December from the 06:00 UTC and the 11:13 UTC we record: (i) the abrupt interruption of infrasonic activity at BN crater; (ii) the beginning of a sudden increment in tremor amplitude that (iii) peaked at about the 11:13 UTC concurrently with the reawakening of a high-energetic infrasonic activity localized along the eruptive fissure (Figure 9). We interpret the three hours-long increase in tremor amplitude as a tracer of the magma- dyke injection and its propagation from the central conduit along the $2 \mathrm{~km}$-long eruptive fissure extending on the western rim of the Valle del Bove. As a result, the timing of the increasing tremor let us suggest a velocity of the intrusion of $0.15-0.2 \mathrm{~m} \mathrm{~s}^{-1}$. The end of 
this excited short-term behavior of seismic and infrasonic activity substantially marked the onset of the fissural activity (Figure 9). This effusive episode was mainly characterized by the violent explosions testified by the high infrasonic activity (Figure 9) and by eruptive vents feeding several lava flow units, extending up to about $2.5 \mathrm{~km}$ (see Figure 6). Notably, the activity along the eruptive fissure caused the interruption of the overflows from the NSEC, suggesting the drainage of the shallow portion of the conduit, because of the opening of the lateral dyke. Moreover, a similar scenario may also explain the lack of infrasonic summit activity as the result of the lateral magma migration from the central conduit to the feeder dyke.

MODIS thermal data acquired after about $10 \mathrm{~h}$ after the beginning of this eruptive episode (24 December at 21:15 UTC) suggests that the lava discharged from the fissure vent(s) with a TADR of $9.2( \pm 3) \mathrm{m}^{3} \mathrm{~s}^{-1}$ (Figure 8). However, on the early 25 December (01:25 UTC) this rate declined to a value of $2.4( \pm 0.7) \mathrm{m}^{3} \mathrm{~s}^{-1}$, indicating a rapid decrease in the effusive activity. This decline is supported by the SENTINEL-2 image of the 26 December 10:00 UTC which tracked the cooling of the lava flow, occurring after less than $48 \mathrm{~h}$ from the beginning of the effusive activity. As a whole, during this fissural eruption we measured an erupted lava volume of about $0.8( \pm 0.2) \mathrm{Mm}^{3}$, to give a total lava volume erupted during the November-December phases of $2.1( \pm 0.6) \mathrm{Mm}^{3}$ (Figure 8).

We must remind that because of the MODIS revisit time (4 image per day), all the short-lived eruptions (such as the 24 December eruption) may be severely underestimated. In this case, our estimate was mainly based to a unique peak thermal value that, however, has been recorded about $12 \mathrm{~h}$ after the onset of the effusive/explosive fissural eruption. Moreover, we know that Etna paroxysmal events such as effusions may be characterized by eruption rate during the first, most energetic phases, largely above the $10 \mathrm{~m}^{3} \mathrm{~s}^{-1}[44,71,72]$. Taking into account that a field report highlighted the high-energetic behavior of the 24 December eruption onset, we stress that the proposed whole erupted volume of $0.8 \mathrm{Mm}^{3}$ for the fissure effusive phase may be significantly underestimated.

As previously cited, the activity that followed the onset of the 24 December episode was marked by the resumption of high infrasonic activity at the BN/VOR craters accompanying strombolian explosions. Notably, this quick renewal of summit explosive activity was coupled with a tremor amplitude that remained well above the pre-eruptive level, also after the complete cessation of the effusive activity (Figure 9).

This feature seems to imply that the shallow magma drainage, occurred during the lateral effusion, enhanced a perturbation in the conduit feeding the Central Craters. Possibly, this fast emptying may have induced a decompression of the active magma column (unloading), with a consequent gas exsolution promoting a resumption of the summit infrasonic detections.

Previously, this interpretation has been invoked to explain sudden explosive behaviors ("paroxysms") at effusive basaltic systems promoting the rapid ascent of a deep undegassed magma batch [72-76]. Here the process has many similarities, with a partial drainage of magma stored in the central conduit [73-75] and a consequent downward depressurization created by the flank effusion. However, the small volume involved during the 24 December short-lived event may fails to trigger the unloading of deeper magma portion but rather cause a strong gas separation promoting related infrasonic and seismic activity. 


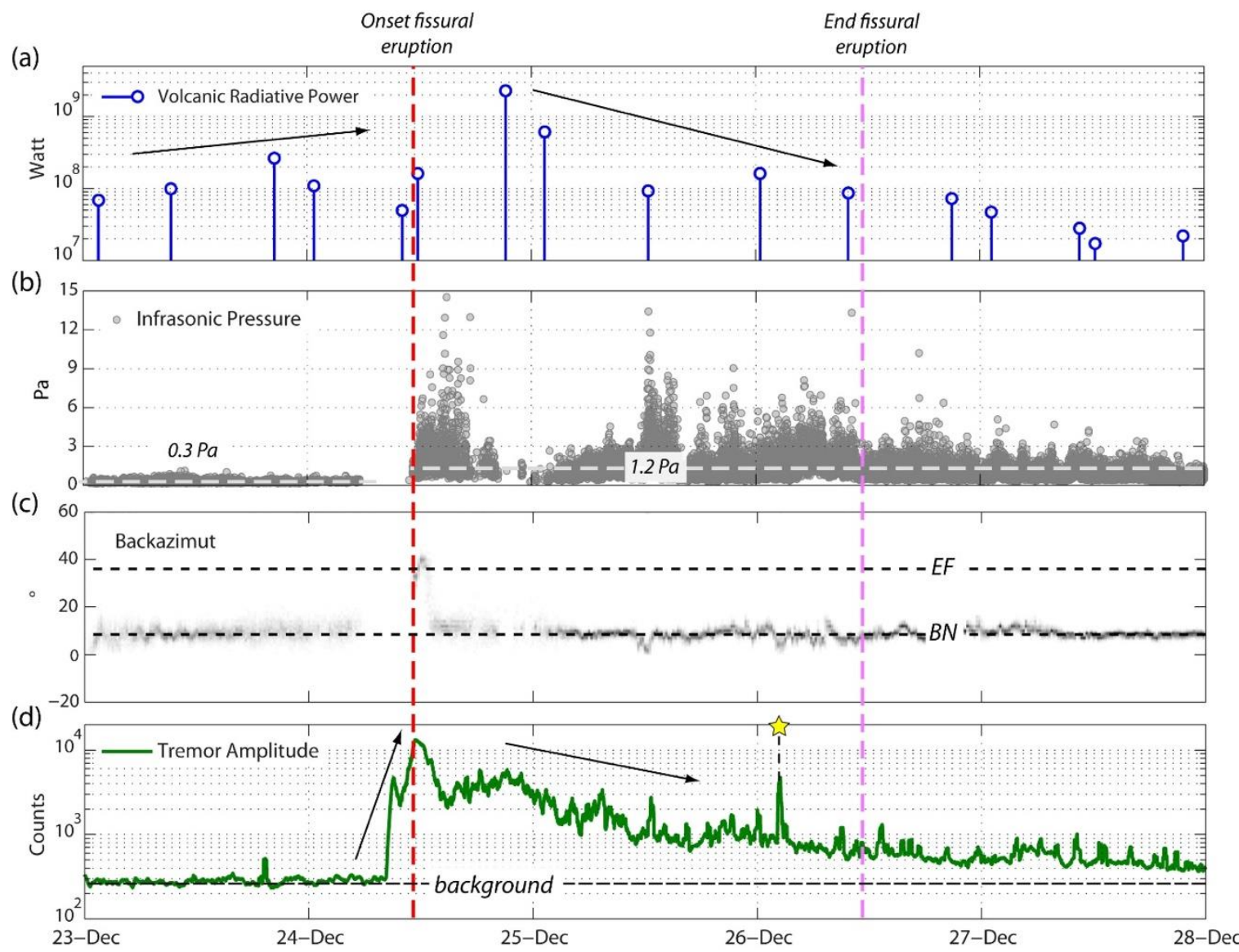

Figure 9. Timeseries of the (a) VRP, (b) Infrasonic Pressure, (c) Infrasonic back-azimuth and (d) Tremor Amplitude focused on the behavior pre-during and after the 24 December Etna fissural activity. See text for details.

\section{Conclusions}

The combined acquisition of ground and space-based data during the September 2018-January 2019 timespan allowed us to track the changes on the Etna volcanic activity and, particularly, the longand short-term precursor signals preceding the 24-26 December fissural eruptive episode.

Our measurements showed that this short-lived activity has been heralded by monthly-long thermal precursor, tracked by MODIS and SENTINEL-2 satellite data, which clearly detect the overflow episodes at NSE crater sector. We link this activity as the surface expression of an upward migration of the active magma column that, moreover, promoted a concurrent increase in summit explosive activity measured by infrasonic arrays. By using MODIS data, we estimate that during this phase about $1.3 \mathrm{Mm}^{3}\left( \pm 0.4 \mathrm{Mm}^{3}\right)$ was erupted from summit vents. The continuous increase in the supply rate pushing in the shallow portion of the magma conduit drive the intrusion of a feeder dyke producing a 2-km long NW-SE direction eruptive fissure. Acquired datasets suggest that the propagation and the emplacement of the dyke occurred at a rate of $0.15-0.20 \mathrm{~m} \mathrm{~s}^{-1}$ during the three-hour long sudden increase in seismic tremor amplitude. This event was the prelude to the take place, along the fissure, of an activity characterized by violent strombolian ash-rich explosions and multiple lava flows and the concurrent interruption of overflows at NSE crater. Notably, the shift from summit and lateral activity has been revealed by the interruption of infrasonic detections at Central Craters and by a subsequent reawakening localized along the opened fissure. During the 24-26 fissural eruption, heat flux reach value typical of effusive activity (2294 MW at 24 December 21:15 UTC), such as the 26 December SENTINEL-2 image acquired at 10:00UTC capture the ending phase of this activity. The resumption of a sustained degassing activity at BN/VOR sector, recorded by the infrasonic data, seems the result of a 
decompression mechanism acting on the central conduit likely due by the magma lateral drainage feeding the fissural activity.

Results highlight that satellite, infrasonic and seismic tremor data represent an invaluable support for the hazard assessment of the wide and complex Etna eruptive scenarios with an impact on the forecasting of its most energetic eruptive episodes. Finally, we stress how the integration of thermal, infrasonic and seismic data make it possible to track the shallow magma movements causing migration of the surface activity and, in general, to detect the main volcanic changes occurred at open-vent volcanoes.

Author Contributions: All of the authors contributed to the manuscript. In detail: M.L. and M.R. conceive the paper. M.L. and F.M. wrote the main sections of the manuscript. D.C., E.M. and F.M. prepare the Method section. M.L., F.M. and D.C. prepared the figures. M.L. and D.C. analyzed the MODIS data. F.M. and D.C. analyze the SENTINEL-2 images. E.M. and G.L. analyzed infrasonic data. E.M., G.L., L.I., M.D.S., M.C.S. and R.G. worked on processing of infrasonic and seismic data. C.C., D.C., M.R. and E.M. supervised the preparation of the manuscript.

Funding: Part of the research leading to these results was performed within the EUROVOLC project (https: //eurovolc.eu) and received funding from the European Community's Horizon 2020 program (grant agreement 731070). The ETN array and infrasound based early warning procedure of eruptive activity at the Etna volcano is performed by UNIFI for the Italian Civil Protection and received funding under the DPC-DEVNET project

Acknowledgments: MIROVA is a collaborative project between the Universities of Turin and Florence (Italy). We acknowledge the LANCE-MODIS data system for providing MODIS Near Real Time products. We acknowledge Copernicus Open Access Hub (https://scihub.copernicus.eu/) and the storage service of Amazon Web Service S3 (AWS-S3, https://registry.opendata.aws/SENTINEL-2/) for the availability and accessibility of SENTINEL-2 dataset. The comments and suggestions of two anonymous reviewers help us to improve the quality of the manuscript.

Conflicts of Interest: The authors declare no conflict of interest.

\section{References}

1. Bonny, E.; Wright, R. Predicting the end of lava flow-forming eruptions from space. Bull. Volcanol. 2017, 79, 52. [CrossRef]

2. Carn, S.A.; Clarisse, L.; Prata, A.J. On the detection and monitoring of effusive eruptions using satellite $\mathrm{SO}_{2}$ measurements. Geol. Soc. Lond. Spec. Publ. 2016, 426, 277-292. [CrossRef]

3. Coppola, D.; Macedo, O.; Ramos, D.; Finizola, A.; Delle Donne, D.; del Carpio, J.; White, R.; McCausland, W.; Centeno, R.; Rivera, M.; et al. Magma extrusion during the Ubinas 2013-2014 eruptive crisis based on satellite thermal imaging (MIROVA) and ground-based monitoring. J. Volcanol. Geotherm. Res. 2015, 302, 199-210. [CrossRef]

4. Pyle, D.M.; Mather, T.A.; Biggs, J. Remote sensing of volcanoes and volcanic processes: Integrating observation and modelling-Introduction. Geol. Soc. Lond. Spec. Publ. 2013, 380, 1-13. [CrossRef]

5. Harris, A.J.L.; Villeneuve, N.; Di Muro, A.; Ferrazzini, V.; Peltier, A.; Coppola, D.; Favalli, M.; Bachèlery, P.; Froger, J.-L.; Gurioli, L.; et al. Effusive crises at Piton de la Fournaise 2014-2015: A review of a multi-national response model. J. Appl. Volcanol. 2017, 6, 1. [CrossRef]

6. Wright, R.; Glaze, L.; Baloga, S.M. Constraints on determining the composition and eruption style of terrestrial lavas from space. Geology 2011, 39, 1127-1130. [CrossRef]

7. Wright, R.; Blackett, M.; Hill-Butler, C. Some observations regarding the thermal flux from Earth's erupting volcanoes for the period 2000 to 2014. Geophys. Res. Lett. 2014, 42, 282-289. [CrossRef]

8. Coppola, D.; Ripepe, M.; Laiolo, M.; Cigolini, C. Modelling satellite-derived magma discharge to explain caldera collapse. Geology 2017, 45, 523-526. [CrossRef]

9. Ganci, G.; Vicari, A.; Cappello, A.; Del Negro, C. An emergent strategy for volcano hazard assessment: From thermal satellite monitoring to lava flow modeling. Remote Sens. Environ. 2012, 119, 197-207. [CrossRef]

10. Gouhier, M.; Guéhenneux, Y.; Labazuy, P.; Cacault, P.; Decriem, J.; Rivet, S. HOTVOLC: A web-based monitoring system for volcanic hot spots. Geol. Soc. Lond. Spec. Publ. 2018, 426, 223-241. [CrossRef]

11. Blackett, M. Early Analysis of Landsat-8 Thermal Infrared Sensor Imagery of Volcanic Activity. Remote Sens. 2014, 6, 2282-2295. [CrossRef]

12. Aufaristama, M.; Hoskuldsson, A.; Jonsdottir, I.; Ulfarsson, M.O.; Thordarson, T. New Insights for Detecting and Deriving Thermal Properties of Lava Flow Using Infrared Satellite during 2014-2015 Effusive Eruption at Holuhraun, Iceland. Remote Sens. 2018, 10, 151. [CrossRef] 
13. Cigolini, C.; Coppola, D.; Yokoo, A.; Laiolo, M. The thermal signature of Aso Volcano during unrest episodes detected from space and ground-based measurements. Earth Planets Space 2018, 70, 67. [CrossRef]

14. Marchese, F.; Neri, M.; Falconieri, A.; Lacava, T.; Mazzeo, G.; Pergola, N.; Tramutoli, V. The Contribution of Multi-Sensor Infrared Satellite Observations to Monitor Mt. Etna (Italy) Activity during May to August 2016. Remote Sens. 2018, 10, 1948. [CrossRef]

15. Mia, M.B.; Fujimitsu, Y.; Nishijima, J. Thermal Activity Monitoring of an Active Volcano Using Landsat 8/OLI-TIRS Sensor Images: A Case Study at the Aso Volcanic Area in Southwest Japan. Geosciences 2017, 7, 118. [CrossRef]

16. Tilling, R.I. The critical role of volcano monitoring in risk reduction. Adv. Geosci. 2008, 14, 3-11. [CrossRef]

17. Rose, W.I.; Palma, J.L.; Delgado Granados, H.; Varley, N. Open-vent volcanism and related hazards: Overview. Geol. Soc. Lond. Spec. Publ. 2013. [CrossRef]

18. Andronico, D.; Branca, S.; Calvari, S.; Burton, M.; Caltabiano, T.; Corsaro, R.A.; Del Carlo, P.; Garfi, G.; Lodato, L.; Miraglia, L.; et al. A multi-disciplinary study of the 2002-03 Etna eruption: Insights into a complex plumbing system. Bull. Volcanol. 2005, 67, 314-330. [CrossRef]

19. Calvari, S.; Spampinato, L.; Lodato, L. The 5 April 2003 vulcanian paroxysmal explosion at Stromboli volcano (Italy) from field observations and thermal data. J. Volcanol. Geotherm. Res. 2006, 149, 160-175. [CrossRef]

20. Aiuppa, A.; Burton, M.; Allard, P.; Caltabiano, T.; Giudice, G.; Gurrieri, S.; Liuzzo, M.; Salerno, G. First observational evidence for the CO2-driven origin of Stromboli's major explosions. Solid Earth 2011, 2, $135-142$. [CrossRef]

21. Ripepe, M.; Pistolesi, M.; Coppola, D.; Delle Donne, D.; Genco, R.; Lacanna, G.; Laiolo, M.; Marchetti, E.; Ulivieri, G.; Valade, S. Forecasting effusive dynamics and decompression rates by magmastatic model at open-vent volcanoes. Sci. Rep. 2017, 7, 3885. [CrossRef]

22. Ripepe, M.; Marchetti, E.; Delle Donne, D.; Genco, R.; Innocenti, L.; Lacanna, G.; Valade, S. Infrasonic early warning system for explosive eruptions. J. Geophys. Res. Solid Earth 2018, 123, 9570-9585. [CrossRef]

23. Alparone, A.; Andronico, D.; Sgroi, T.; Ferrari, F.; Lodato, L.; Reitano, D. Alert system to mitigate tephra fallout hazards at Mt. Etna volcano, Italy. Nat. Hazards 2007, 43, 333-350. [CrossRef]

24. Bonaccorso, A.; Cannata, A.; Corsaro, R.A.; Di Grazia, G.; Gambino, S.; Greco, F.; Miraglia, L.; Pistorio, A. Multidisciplinary investigation on a lava fountain preceding a flank eruption: The 10 May 2008 Etna case. Geochem. Geophys. Geosyst. 2011, 12, Q07009. [CrossRef]

25. Calvari, S.; Cannavò, F.; Bonaccorso, A.; Spampinato, L.; Pellegrino, A.G. Paroxysmal Explosions, Lava Fountains and Ash Plumes at Etna Volcano: Eruptive Processes and Hazard Implications. Front. Earth Sci. 2018. [CrossRef]

26. Scollo, S.; Prestifilippo, M.; Pecora, E.; Corradini, S.; Merucci, L.; Spata, G.; Coltelli, M. Eruption column height estimation of the 2011-2013 Etna lava fountains. Ann. Geophys. 2014, 57, S0214. [CrossRef]

27. Allard, P. Endogenous magma degassing and storage at mount etna. Geophys. Res. Lett. 1997, 24, $2219-2222$. [CrossRef]

28. Allard, P.; Behncke, B.; D'Amico, S.; Neri, M.; Gambino, S. Mount Etna 1993-2005: Anatomy of an evolving eruptive cycle. Earth Sci. Rev. 2006, 78, 85-114. [CrossRef]

29. Corsaro, R.A.; Andronico, D.; Behncke, B.; Branca, S.; Caltabiano, T.; Ciancitto, F.; Cristaldi, A.; De Beni, E.; La Spina, A.; Lodato, L.; et al. Monitoring the December 2015 summit eruptions of Mt. Etna (Italy): Implications on eruptive dynamics. J. Volcanol. Geotherm. Res. 2017, 341, 53-69. [CrossRef]

30. Behncke, B.; Branca, S.; Corsaro, R.A.; De Beni, E.; Miraglia, L.; Proietti, C. The 2011-2012 summit activity of Mount Etna: Birth, growth and products of the new SE crater. J. Volcanol. Geotherm. Res. 2014, 270, 10-21. [CrossRef]

31. Neri, M.; De Maio, M.; Crepaldi, S.; Suozzi, E.; Lavy, M.; Marchionatti, F.; Calvari, S.; Buongiorno, M.F. Topographic maps of Mount Etna's summit craters, updated to December 2015. J. Maps 2017, 13, 674-683. [CrossRef]

32. Andronico, D.; Lodato, L. Effusive activity at Mount Etna volcano (Italy) during the 20th century: A contribution to volcanic hazard assessment. Nat. Hazards 2005, 36, 407-443. [CrossRef]

33. Branca, S.; Del Carlo, P. Types of eruptions of Etna Volcano AD 1670-2003: Implications for short-term eruptive behaviour. Bull. Volcanol. 2005, 67, 732-742. [CrossRef]

34. Neri, M.; Acocella, V.; Behncke, B.; Giammanco, S.; Mazzarini, F.; Rust, D. Structural analysis of the eruptive fissures at Mount Etna (Italy). Ann. Geophys. 2011, 54, 464-479. 
35. Giuffrida, M.; Viccaro, M.; Ottolini, L. Ultrafast syn-eruptive degassing and ascent trigger high-energy basic eruptions. Sci. Rep. 2018, 8, 147. [CrossRef] [PubMed]

36. Acocella, V.; Neri, M. What makes flank eruptions? The 2001 Etna eruption and the possible triggering mechanisms. Bull. Volcanol. 2003, 65, 517-529. [CrossRef]

37. Bonaccorso, A.; Calvari, S.; Boschi, E. Hazard mitigation and crisis management during major flank eruptions at Etna volcano: Reporting on real experience. Geol. Soc. Lond. Spec. Publ. 2016, 426, 447-461. [CrossRef]

38. Acocella, V.; Neri, N.; Behncke, B.; Bonforte, A.; Del Negro, C.; Ganci, G. Why does a mature volcano need new vents? The case of the New Southeast Crater at Etna. Front. Earth Sci. 2016, 4, 67. [CrossRef]

39. De Beni, E.; Behncke, B.; Branca, S.; Nicolosi, I.; Carluccio, R.; D'Ajello Caracciolo, F.; Chiappini, M. The continuing story of Etna's New Southeast Crater (2012-2014): Evolution and volume calculations based on field surveys and aerophotogrammetry. J. Volcanol. Geotherm. Res. 2015, 303, 175-186. [CrossRef]

40. Gambino, S.; Cannata, A.; Cannavò, F.; La Spina, A.; Palano, M.; Sciotto, M.; Spampinato, L.; Barberi, G. The unusual 28 December 2014 dike-fed paroxysm at Mount Etna: Timing and mechanism from a multidisciplinary perspective. J. Geophys. Res. 2016, 121, 2037-2053. [CrossRef]

41. Barberi, G.; Giampiccolo, E.; Musumeci, C.; Scarfi, L.; Bruno, V.; Cocina, O.; Díaz-Moreno, A.; Sicali, S.; Tusa, G.; Tuvè, T.; et al. Seismic and volcanic activity during 2014 in the region involved by TOMO-ETNA seismic active experiment. Ann. Geophys. 2016, 59, 4. [CrossRef]

42. Cappello, S.; Ganci, G.; Bilotta, G.; Herault, A.; Zago, V.; Del Negro, C. Satellite-driven modeling approach for monitoring lava flow hazards during the 2017 Etna eruption. Ann. Geophys. 2018, 61, 13. [CrossRef]

43. Ganci, G.; Bilotta, G.; Cappello, A.; Hérault, A.; Del Negro, C. HOTSAT: A multiplatform system for the satellite thermal monitoring of volcanic activity. Geol. Soc. Lond. Spec. Publ. 2016, 426, 207-221. [CrossRef]

44. Ganci, G.; Cappello, S.; Bilotta, G.; Herault, A.; Zago, V.; Del Negro, C. Mapping Volcanic Deposits of the 2011-2015 Etna Eruptive Events Using Satellite Remote Sensing. Front. Earth Sci. 2018. [CrossRef]

45. Laboratorio di Geofisica Sperimentale. Available online: http://gs.geo.unifi.it/index.php/reports/etna (accessed on 26 December 2018).

46. Harris, A.J.L.; Steffke, A.; Calvari, S.; Spampinato, L. Thirty years of satellite-derived lava discharge rates at Etna: Implications for steady volumetric output. J. Geophys. Res. 2011, 116, B08204. [CrossRef]

47. Istituto Nazionale di Geofisica e Vulcanologia. Bollettino Settimanale, Rep. $N^{\circ}$ 01/2019. Available online: http://www.ct.ingv.it/it/rapporti/multidisciplinari.html (accessed on 26 December 2018).

48. Istituto Nazionale di Geofisica e Vulcanologia. Catalogo Nazionale Terremoti. Available online: http: //cnt.rm.ingv.it/event/21285011 (accessed on 26 December 2018).

49. Coppola, D.; Laiolo, M.; Cigolini, C.; Delle Donne, D.; Ripepe, M. Enhanced volcanic hot-spot detection using MODIS IR data: Results from the MIROVA system. Geol. Soc. Lond. Spec. Publ. 2016, 426, 181-205. [CrossRef]

50. Wooster, M.J.; Zhukov, B.; Oertel, D. Fire radiative energy for quantitative study of biomass burning: Derivation from the BIRD experimental satellite and comparison to MODIS fire products. Remote Sens. Environ. 2003, 86, 83-107. [CrossRef]

51. Harris, A.J.L.; Baloga, S.M. Lava discharge rates from satellite-measured heat flux. Geophys. Res. Lett. 2009, 36, L19302. [CrossRef]

52. Pieri, D.; Baloga, S.M. Eruption rate, area, and length relationships for some Hawaiian lava flows. J. Volcanol. Geotherm. Res. 1986, 30, 29-45. [CrossRef]

53. Wright, R.; Blake, S.; Harris, A.J.L.; Rothery, D.A. A simple explanation for the space-based calculation of lava eruption rates. Earth Planet. Sci. Lett. 2001, 192, 223-232. [CrossRef]

54. Harris, A.J.L. Thermal Remote Sensing of Active Volcanoes. A User's Manual; Cambridge University Press: Cambridge, UK, 2013; p. 736.

55. Coppola, D.; Laiolo, M.; Piscopo, D.; Cigolini, C. Rheological control on the radiant density of active lava flows and domes. J. Volcanol. Geotherm. Res. 2018, 249, 39-48. [CrossRef]

56. Francis, P.; Oppenheimer, C.; Stevenson, D. Endogenous growth of persistently active volcanoes. Nature 1993, 366, 554-557. [CrossRef]

57. Harris, A.J.L.; Stevenson, D. Magma budgets and steady-state activity of Vulcano and Stromboli. Geophys. Res. Lett. 1997, 24, 1043-1046. [CrossRef] 
58. Aiuppa, A.; de Moor, J.M.; Arellano, S.; Coppola, D.; Francofonte, V.; Galle, B.; Giudice, G.; Liuzzo, M.; Mendoza, E.; Saballos, A.; et al. Tracking formation of a lava lake from ground and space: Masaya volcano (Nicaragua), 2014-2017. Geochem. Geophys. Geosyst. 2018, 19, 496-515. [CrossRef]

59. D'Aleo, R.; Bitetto, M.; Delle Donne, D.; Coltelli, M.; Coppola, D.; McCormick Kilbride, B.; Pecora, E.; Ripepe, M.; Salem, L.C.; Tamburello, G.; et al. Understanding the SO2 Degassing Budget of Mt Etna's Paroxysms: First Clues from the December 2015 Sequence. Front. Earth Sci. 2018. [CrossRef]

60. Coppola, D.; Piscopo, D.; Laiolo, M.; Cigolini, C.; Delle Donne, D.; Ripepe, M. Radiative heat power at Stromboli volcano during 2000-2011: Twelve years of MODIS observations. J. Volcanol. Geotherm. Res. 2012, 215-216, 48-60. [CrossRef]

61. Massimetti, F.; Coppola, D.; Laiolo, M.; Cigolini, C.; Ripepe, M. First comparative results from SENTINEL-2 and MODIS-MIROVA volcanic thermal dataseries. In Proceedings of the CoV10 IAVCEI General Assembly, Naples, Italy, 2-7 September 2018.

62. Murphy, S.W.; de Souza Filho, C.R.; Wright, R.; Sabatino, G.; Pabon, R.C. HOTMAP: Global hot target detection at moderate spatial resolution. Remote Sens. Environ. 2016, 177, 78-88. [CrossRef]

63. Marchetti, E.; Ripepe, M.; Ulivieri, G.; Caffo, S.; Privitera, E. Infrasonic evidences for branched conduit dynamics at Mt. Etna volcano, Italy. Geophys. Res. Lett. 2009, 36, L19308. [CrossRef]

64. Ulivieri, G.; Ripepe, M.; Marchetti, E. Infrasound reveals transition to oscillatory discharge regime during lava fountaining: Implication for early warning. Geophys. Res. Lett. 2013, 40, 3008-3013. [CrossRef]

65. Ripepe, M.; Marchetti, E. Array tracking of infrasonic sources at Stromboli volcano. Geophys. Res. Lett. 2002, 29, 2076. [CrossRef]

66. Ripepe, M.; Marchetti, E.; Ulivieri, G. Infrasonic monitoring at Stromboli volcano during the 2003 effusive eruption: Insights on the explosive and degassing process of an open conduit system. J. Geophys. Res. 2007, 112, B09207. [CrossRef]

67. Ulivieri, G.; Marchetti, E.; Ripepe, M.; Chiambretti, I.; De Rosa, G.; Segor, V. Monitoring snow avalanches in Northwestern Italian Alps using an infrasound array. Cold Reg. Sci. Technol. 2011, 69, 177-183. [CrossRef]

68. Istituto Nazionale di Geofisica e Vulcanologia. Bollettini Settimanali Rep. $N^{\circ}$ 48/2018. Available online: http://www.ct.ingv.it/it/rapporti/multidisciplinari.html (accessed on 27 December 2018).

69. Istituto Nazionale di Geofisica e Vulcanologia. Bollettini Settimanali Rep. $N^{\circ}$ 52/2018. Available online: http://www.ct.ingv.it/it/rapporti/multidisciplinari.html (accessed on 27 December 2018).

70. Istituto Nzionale di Geofisica e Vulcanologia. Available online: https://ingvterremoti.wordpress.com/ 2018/12/26/approfondimento-e-aggiornamento-sullattivita-sismica-e-vulcanica-in-area-etnea/ (accessed on 27 December 2018).

71. Wadge, G. Effusion rate and the shape of aa lava flow-fields on Mount Etna. Geology 1978, 6, 503-506. [CrossRef]

72. Calvari, S.; Salerno, G.G.; Spampinato, L.; Gouhier, M.; La Spina, A.; Pecora, E.; Harris, A.J.L.; Labazuy, P.; Biale, E.; Boschi, E. An unloading foam model to constrain Etna's 11-13 January 2011 lava fountaining episode. J. Geophys. Res. Solid Earth 2011, 116, 1-18. [CrossRef]

73. Calvari, S.; Spampinato, L.; Bonaccorso, A.; Oppenheimer, C.; Rivalta, E.; Boschi, E. Lava effusion-A slow fuse for paroxysms at Stromboli volcano? Earth Planet. Sci. Lett. 2011, 301, 317-323. [CrossRef]

74. Valade, S.; Lacanna, G.; Coppola, D.; Laiolo, M.; Pistolesi, M.; Delle Donne, D.; Genco, R.; Marchetti, E.; Ulivieri, G.; Allocca, C.; et al. Tracking dynamics of magma migration in open-conduit systems. Bull. Volcanol. 2016, 78, 78. [CrossRef]

75. Ripepe, M.; Delle Donne, D.; Genco, R.; Maggio, G.; Pistolesi, M.; Marchetti, E.; Lacanna, G.; Ulivieri, G.; Poggi, P. Volcano seismicity and ground deformation unveil the gravity-driven magma discharge dynamics of a volcanic eruption. Nat. Commun. 2015, 6, 6998. [CrossRef]

76. Coppola, D.; Di Muro, A.; Peltier, A.; Villeneuve, N.; Ferrazzini, V.; Favalli, M.; Bachèlery, P.; Gurioli, L.; Harris, A.J.L.; Moune, S.; et al. Shallow system rejuvenation and magma discharge trends at Piton de la Fournaise volcano (La Réunion Island). Earth Planet. Sci. Lett. 2017, 463, 13-24. [CrossRef]

(C) 2019 by the authors. Licensee MDPI, Basel, Switzerland. This article is an open access article distributed under the terms and conditions of the Creative Commons Attribution (CC BY) license (http://creativecommons.org/licenses/by/4.0/). 